\title{
The Bengal Fan: Some Preliminary Results from ODP Drilling
}

\author{
Dorrik A. V. Stow, ${ }^{1}$ James R. Cochran, ${ }^{2}$ and ODP Leg 116 Shipboard Scientific Party* \\ 'Geology Department, University of Nottingham, Nottingham, NG7 2RD England; and \\ ${ }^{2}$ Lamont-Doherty Geological Observatory, Palisades, NY, USA
}

\begin{abstract}
Three deep holes, with a maximum penetration of $960 \mathrm{~m}$ below sea floor, were drilled into the distal Bengal Fan just south of the equator during ODP Leg 116. The entire section recovered is dominated by sandy silt and mud turbidites derived from the Ganges Delta and from the continental margin of the western Bay of Bengal, interbedded with thin pelagic clays and with biogenic turbjdites probably from a local sea mount source. The effects of Himalayan uplift, sea level fluctuations, local tectonics, and fan channel/lobe processes have closely interacted to produce the observed sedimentary record of the past 17 million years since the early Miocene.
\end{abstract}

\footnotetext{
*Coauthors include: James R. Cochran, Lamont-Doherty Geological Observatory (Co-chief scientist); Dorrik A. V. Stow, Nottingham University, England (Co-chief scientist); Christian A. Auroux, Texas A \& M University, USA (ODP staff scientist); Kazou Amano, Ibaraki University, Japan; Peter S. Balson, British Gcological Survey, Keyworth, Notts, England; Jacques Boulegue, Pierre \& Marie Curic University, Paris, France; Garrett W. Brass, University of Miami, Florida, USA; Jeffrey Corrigan, University of Texas, Austin. USA: Stefan Gartner, Texas A \& M University, USA; Stuart A. Hall, University of Houston, Texas, USA; Silvia laccarino, University of Parma, Italy; Toshio Ishizuka. University of Tokyo, Japan; Irena Kacmarska, Mount Allison University, New Brunswick, Canada; Heidemarie Kassens, Kiel University, West Germany; Gregory Leger, Dalhousie University, Halifax. Nova Scotia, Canada; Franca Proto Decima, University of Padova, Italy; C. V. Raman, Andhra University, Visakhapatnam, India; William W. Sager, Texas A \& M University, USA; Kozo Takahashi, Woods Hole Occanographic Institution, USA: Thomas Thompson, 580 Euclid Ave, Boulder, Colo, USA; Jean-Jacques Tiercelin, University of Bretagne, Brest, France; Mark Townsend, University of Nottingham, England; Andreas Wetzel, Tubingen University, West Germany; N. P. Wijayananda, National Aquatatic Resource Agency, Colombo, Sri Lanka; and Colin Williams, Lamont-Doherty Geological Observatory.
}

\section{Introduction}

Leg 116 of the Ocean Drilling Program (ODP) provided one of the few opportunities to drill into one of the world's largest submarine fans. Leg 96 of the Deep Sea Drilling Program (DSDP) drilled a series of sites on the mid- and lower Mississippi Fan (Bouma and others 1985,1986$)$ and several earlier legs have drilled isolated holes on the Bengal (Von der Borsch and others 1974), Indus (Whitmarsh 1974), Amazon (Hayes and others 1973), Nile (Ryan and others 1973), and Zambesi (Simpson and others 1974) Fans. These elongate submarine fans (Stow and others 1983) are large and complex and require much further study before a full picture of their characteristics can be pieced together.

The Bengal Fan, together with its eastern lobe, the Nicobar Fan, is the world's largest submarine fan (Von der Borsch and others 1974, Curray and Moore 1971, Curray and others 1982, Emmel and Curray 1984) covering an area of $3 \times 10^{6} \mathrm{~km}^{2}$ (Fig. 1). It is $2800-$ $3000 \mathrm{~km}$ long, $830-1430 \mathrm{~km}$ wide, and over $16 \mathrm{~km}$ thick beneath the northern Bay of Bengal. Fewer than 100 piston cores have been recovered from the surface sediments, and only one spot-cored DSDP site (Leg 22, Site 218) has been drilled into the fan. This hole terminated in mid-Miocene sediments at a depth of $772 \mathrm{~m}$ below the sea floor. Four main pulses of sandy turbidites were identified, one in the mid-Miocene, two in the late Miocene-Pliocene and one in the Pleistocene (Von der Borsch and others 1974). The piston cores from the fan show that in most cases pelagic muds, $20-90 \mathrm{~cm}$ thick, are found overlying thin turbidite sands, most less than $10 \mathrm{~cm}$ thick. 


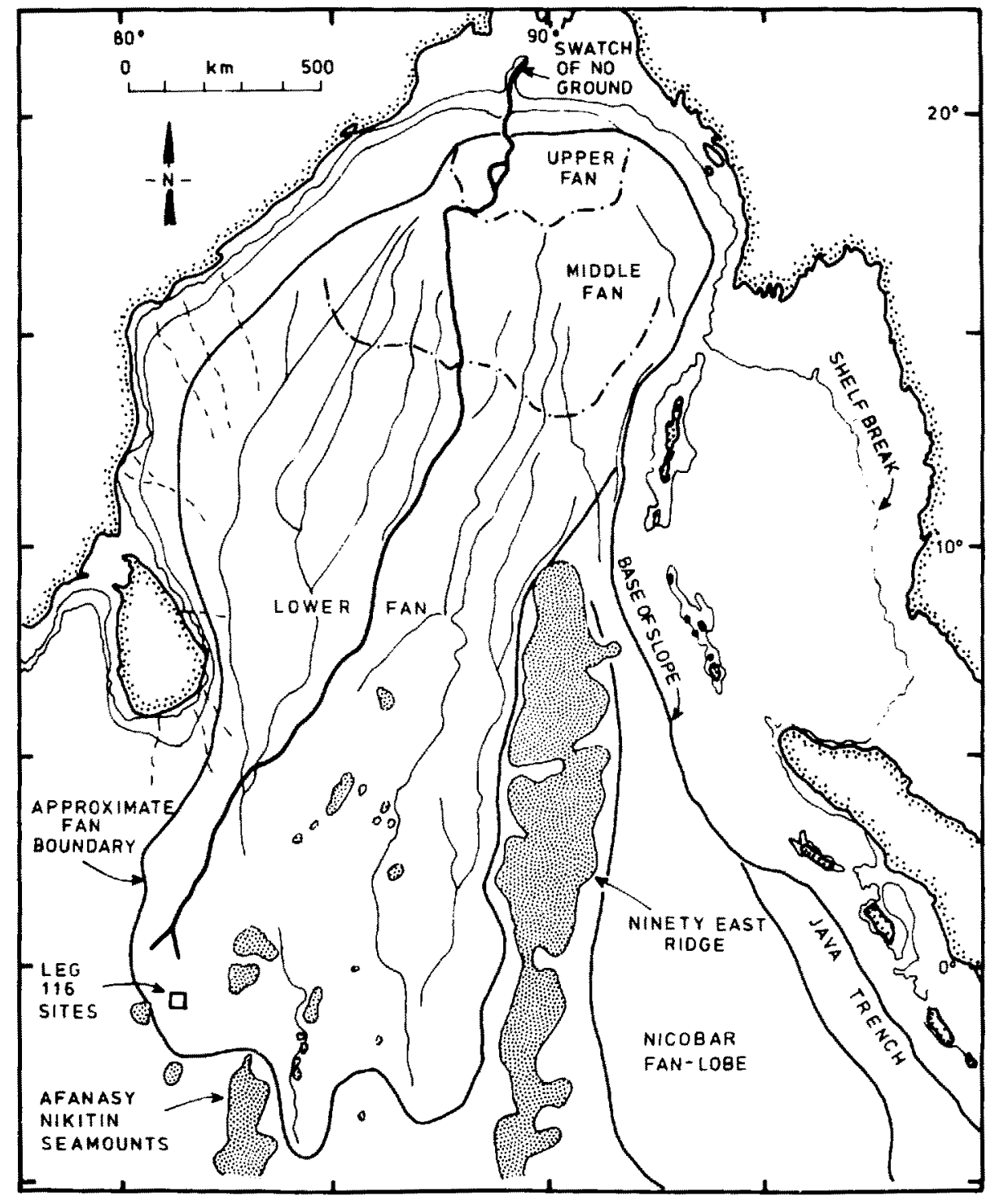

Figure 1. Map of the Bengal Fan (Modified after Emmel and Curray (1984) and location of Leg 116 sites. Indian margin and fan channels shown by dashed lines: currently active fan channel shown by solid line. Seamounts and topographic highs indicated by a heavy shading.
Sediments are funnelled to the fan via a delta-front trough, the "Swatch of No Ground' (Fig. 1). This trough is presently connected to only one active fan channel, but has been effectively cut off from its principal sediment supply and the Ganges/Brahmaputra Delta, since the most recent rise in sea level, probably about 7,000-10,000 BP. Many other channels mark the fan surface and extend for various distances along its length. Most of these are thought to have been abandoned by channel switching in the past (Emmel and Curray 1984). Several canyons and channels also cut across the east Indian margin, extending into the western part of the fan (Fig. 1).

In this article, we present some preliminary shipboard results from Leg 116 drilling regarding fan growth and sediment characteristics. Other observa- tions are published elsewhere (The Leg 116 Shipboard Scientific Party 1987a, 1987b).

These deal more specifically with the other main scientific objectives of the Leg, namely the history of Himalayan uplift as recorded in the accumulation of their erosion products on the Bengal Fan, and the nature and timing of intraplate deformation in the central Indian Ocean (Weissel, Anderson, and Geller 1980). It is clear from this preliminary work that the history of the Bengal Fan and hence of Himalayan uplift goes back to at least 17 (Ma). From a consideration of seismic records in the area it seems likely that a major uplift event occurred around 18-20 Ma in the early Miocene. Intraplate deformation began to affect this part of the Indian Ocean about $7 \mathrm{Ma}$. Motion along high-angle faults between blocks has been 
gradual since that time at an average rate of approximately $50 \mathrm{~m}$ per million years (m.y.).

\section{Results}

Three closely-spaced sites were drilled on the extreme distal portion of the fan, some $800 \mathrm{~km}$ south of Sri Lanka and $200 \mathrm{~km}$ northwest of the main Afanasy Nikitin Seamount group (Fig. 1). The most recently active fan channel appears to terminate some $50 \mathrm{~km}$ to the north and the sea floor in the area of drilling is smooth and almost flat $(<0.5 \mathrm{~m} / \mathrm{km}$ gradient). It is not yet clear, pending further study of $3.5 \mathrm{kHz}$ seismic and depth-profile lines, whether the area shows morphological characteristics of a terminal lobe or a smooth lower fan.

However, beneath this generally smooth fan surface, the ocean crust and overlying sediments have been deformed into long-wavelength $(100-300 \mathrm{~km})$ undulations (Weissel and others 1980, Geller and others 1983) that locally protrude through the younger sediment cover giving a sea floor relief of up to 800 $\mathrm{m}$. Superimposed on these undulations are faulted and rotated blocks spaced $5-20 \mathrm{~km}$ apart; these features result in a few tens of meters of sea floor relief where the top of the fault block is exposed (Fig. 2(a)).

All three sites penetrated a similar sequence of sediments but showed significant differences in thickness due to their relative positions on two adjacent fault blocks (Fig. 2). At each site, five major lithologic units can be recognized, from top to bottom:

- Unit I - the topmost 2-6 m of pelagic clayey oozes and mud turbidites

- Unit II - 100-150 m of sandy silt, silt-to-mud and mud turbidites

- Unit III - 10-150 m of thin to thick mud turbidites interbedded with pelagic clays and biogenic turbidites

- Unit IV - 70-230 m of interbedded silt and mud turbidites with pelagic clays and rare biogenic turbidites

- Unit V - the lower section at all sites (775 m thick at Site 718 ) is dominated by silt and silt-to-mud turbidites, with reddish-brown and green-coloured thin-bedded turbidites and pelagic clays common in the lower part (Unit Vb).

Coring was continuous at each of the three sites although core recovery was very variable, being poor in the silts and good in the mud-dominated sections. Recovery averaged $60 \%$ at Site $717,30 \%$, at Site 718 and $40 \%$ at Site 719 . Closely-spaced samples (at least one per core) have been processed for biostratigraphic control. Although some of the silt turbidites are completely barren and others contain a sparse, relatively solution-resistant, mainly nannofossil biota, the downhole biostratigraphy is consistant and adequately constrained.

\section{Sediment Facies}

The entire section penetrated is dominated by turbidites. The most common of these are gray micaceous silt and silt-to-mud turbidites that range up to $2.5 \mathrm{~m}$ in thickness (Facies 1, Fig. 3). Some turbidite beds have 1.0 to $1.5 \mathrm{~m}$ of graded silt at the base, whereas others have no more than a few thin silt laminae, overlain by up to $2.0 \mathrm{~m}$ of graded mud. Indistinct parallel lamination is common in the thicker beds, whereas the thinner beds $(1-10 \mathrm{~cm}$ thick) may show graded laminated units and, more rarely, cross and convolute lamination. Wood fragments (up to $2 \mathrm{~cm}$ long) are locally abundant in the silts, and bioturbation is rare at the tops of the mud interval. The maximum quartz grain size at the base of the thicker silt turbidites is coarse sand grade, although the mean grain size is coarse silt to find sand.

Dark gray mud turbidites are common in certain intervals (particularly Units III and IV), ranging in thickness from a few $\mathrm{cm}$ to $1.5 \mathrm{~m}$ (Facies 2, Fig. 3). These turbidites typically consist of silty mud which grades up into dark gray clay that is bioturbated toward the top. Locally, the base is characterized by thin $(0.5-5.0 \mathrm{~cm})$ silt-laminated muds. Very finegrained dispersed woody debris is ubiquitous, resedimented nannofossils are common, and iron sulphides are locally abundant as finely dispersed framboids, thin mycelia, and larger pyritized burrows, microfossils, pyritic silt, and concretions. One intriguing aspect of these dark gray, organic-carbon-rich turbidites is that they have a very high magnetic susceptibility signature, with variations that reflect the grading. The susceptibility values are typically highest in the basal silts and decrease upward through the turbidite.

Two types of biogenic turbidites are locally (Units III, IV and $\mathrm{Vb}$ ) interbedded with the terrigenous sediments (Facies 3, Fig. 3); (1) thick-bedded (20-150 $\mathrm{cm})$, greenish-colored nannofossil/clay-rich turbidites, in some cases with a 1.0 to $10.0 \mathrm{~cm}$ thick laminated foraminifer-rich silt base; and (2) thinner-bedded (typically $3-15 \mathrm{~cm}$ ), whitish colored turbidites, either with a high percentage of benthic foraminifers, or of mainly unidentifiable carbonate silts (especially deeper within the section at Site 718).

Thin pelagic beds (Facies 4 and 5, Fig. 3) occur at the tops of many of the mud and biogenic turbidites, and also above thin-bedded greenish-colored silt-mud turbidites that are characteristic of Unit $\mathrm{Vb}$. Pelagic clayey oozes (Facies 5, Fig. 3) are only present within 

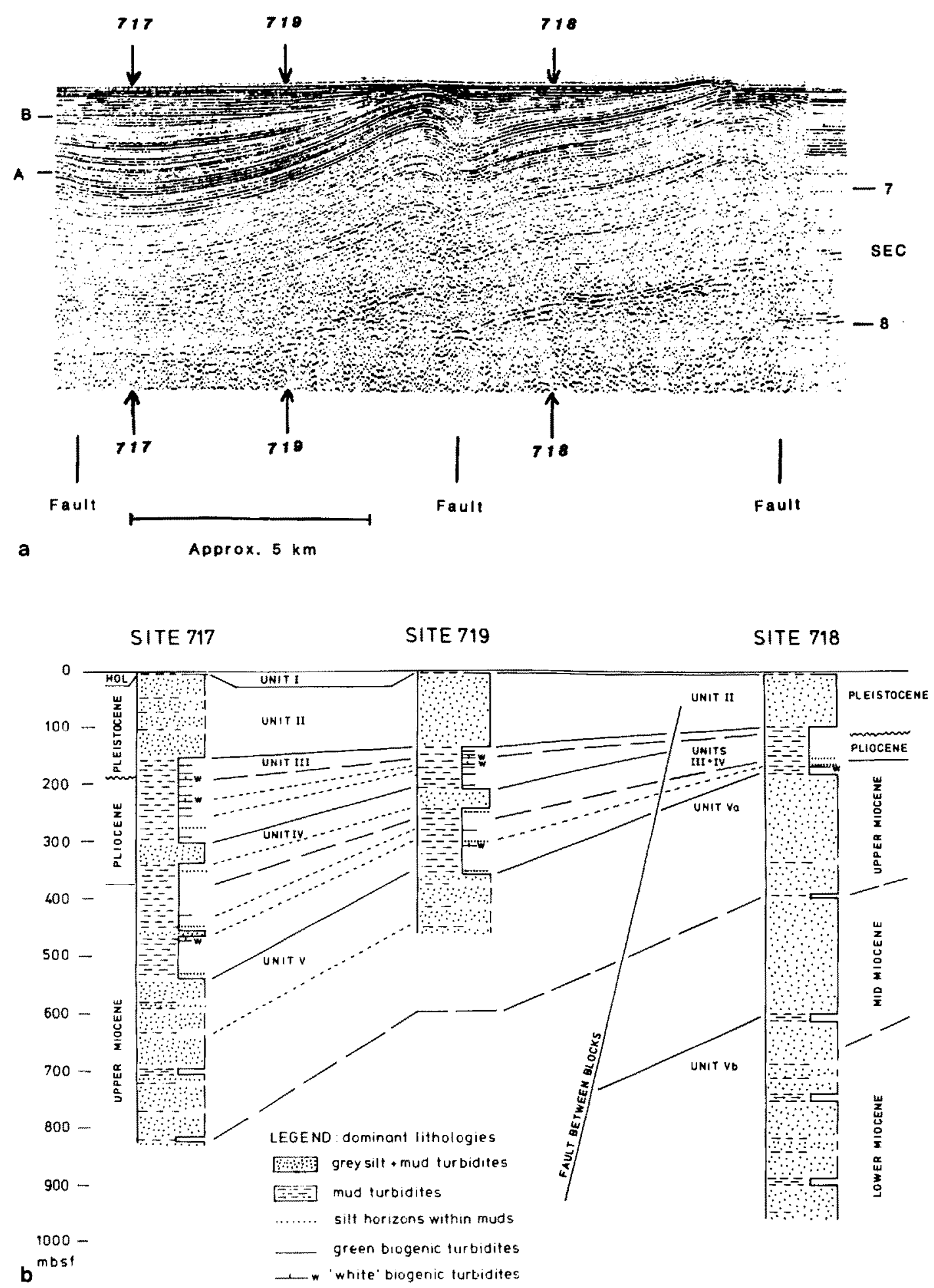

Figure 2. (a) Single channel reflection profile across the Leg 116 sites, (b) Summary lithostratigraphic sections of Sites 717, 718, and 719 showing lithologic units and correlations (from the Leg 116 Shipboard Scientific Party 1987a,b). 
the top meter of section. Calcareous pelagic clays with residual, solution-resistant microfossils, occur in sediments back to about $2 \mathrm{Ma}$, and then give way downsection to pale-colored, bioturbated, pelagic clays characterized by zeolites, manganiferous chemical fronts, and an absence of fossils. From about $10 \mathrm{Ma}$ to the base of the recovered section (about $18 \mathrm{Ma}$ ) there is an increasing proportion of greenish and reddish-brown, bioturbated, and unfossiliferous pelagic clays.

There is one particularly interesting sediment type that is not readily interpreted as either turbiditic or pelagic in origin. These muds may be either light or dark gray in color, similar in composition to the typical mud turbidites but without distinct bed boundaries or regular grading, and commonly bioturbated throughout. In some cases, the burrowing appears to extend both from the base of the bed upward and from the top of the bed downward. This facies may be thin or thick-bedded (up to $1.0 \mathrm{~m}$ thick) and is most prevalent in the attenuated intervals at Sites 718 and 719. We tentatively interpret these as being deposited either from the cloudy suspension mixed high up into the water column beyond where the "true" turbidity current has reached, or from the dilute suspension behind and above the tail of a turbidity current that has passed by an area without depositing any of its load.

\section{Rate and Frequency}

Biostratigraphic control in the lower fan sediments is based for the most part on a sparse, relatively solution-resistant, mainly nannofossil biota that is entirely resedimented. Nevertheless, within these limitations a very consistant biostratigraphy has emerged at each of the three sites, so that some estimates can be made of the sediment accumulation rates and frequency of turbidity current events on the distal fan.

The average sedimentation rate for the thickest, most complete section drilled is $50-60 \mathrm{~m} / \mathrm{m}$.y., but there are great variations within the $17 \mathrm{Ma}$ period cored. The topmost Holocene/latest Pleistocene sediments (Unit I) accumulated relatively slowly at $15-25 \mathrm{~m} /$ m.y. The silty turbidites of late Pleistocene age (Unit II) were deposited much more rapidly, probably at a rate in excess of $350 \mathrm{~m} / \mathrm{m} . \mathrm{y}$. Other silty turbidite sections (top of Unit 4, Unit 5) show average rates of $70-200 \mathrm{~m} / \mathrm{m} . \mathrm{y}$, but these figures probably mask periods of slower more pelagic and faster more turbiditic deposition. The muddy turbidite section (Units III and IV) accumulated at a slower average rate of less than $70 \mathrm{~m} / \mathrm{m}$.y. At all three sites drilled, there is either a hiatus or an extremely condensed sedimentary section that represents approximately $1 \mathrm{~m} . \mathrm{y}$. of the early Pleistocene.
Our preliminary estimates of turbidite frequency in the immediate area of the Leg 116 sites show marked differences between turbidite types. The gray silt and turbidites appear to have reached the distal fan with a frequency of about one every 1000 years during the Miocene and late Pleistocene; the dark gray mud turbidites, once every 10,000 to 15,000 years during the latest Miocene and Pliocene; and the green biogenic turbidites of Unit III much less regularly, on the order of one every 100,000 years. However, we assume that each turbidite covers a small part of the fan, therefore the total frequency of turbidity currents is much higher over the fan as a whole.

\section{Cycles and Sequences}

Several orders or scales of sequences can be recognized both in the recovered cores and in the wireline logs, which were obtained from two or the sites. On the large scale (Lithologic Units), there is an alternation of more silty and more muddy units, similar to that observed at Site 218 (Von der Borsch and others 1974). This indicates a response to both sea-level fluctuation and Himalayan tectonics as we will show.

On a scale of a few tens of meters, there is variation within the lower silty unit (Unit V) between intervals 5 to $20 \mathrm{~m}$ thick of very thin-bedded turbidites and pelagic clays, and somewhat thicker sections (up to $60 \mathrm{~m}$ ) of medium to thick-bedded silt and silt-mud turbidites without identifible pelagic layers. These meso-sequences of vertical variation in turbidite thickness and coarseness appear to be of an oscillation or symmetrical type (e.g. Stow 1985) and we would interpret them as most likely reflecting changes in development of the lower fan by lobe or channel switching.

Small-scale sequences from about 5 to $15 \mathrm{~m}$ thick occur in both the mud-rich and silt-rich intervals (Units III, IV and V) superimposed upon the meso-scale sequences described above. These small-scale sequences show variation in turbidite thicknesses arranged in both thinning- and thickening-upward cycles. These we provisionally interpret as turbidite compensation cycles (Mutti and Sonnino 1981, Mutti and Normark 1987) similar to those observed on the Mississippi Fan (Stow and others 1986).

The upward decrease in turbidite thickness over a few beds would thus be related to successive turbidity currents being affected by the slight positive relief of the previously deposited turbidite and hence veering to one side or the other. The upward increase in thicknesses is the reciprocal effect of this slight lateral deflection of individual turbidite depocenters that occurs adjacent to an upward decreasing sequence. 


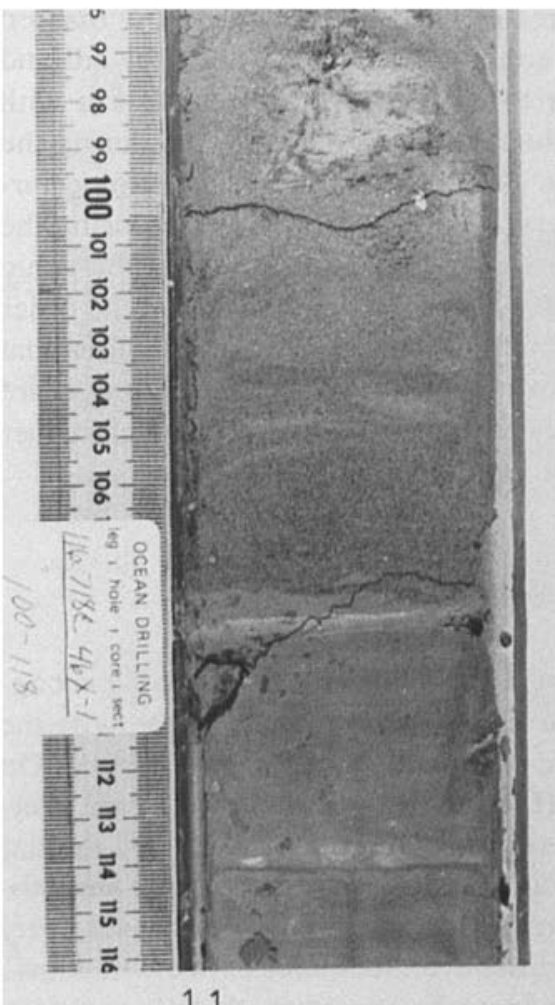

1.1

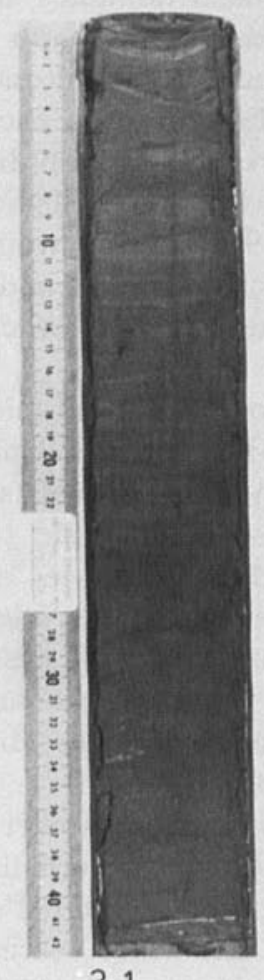

3.1

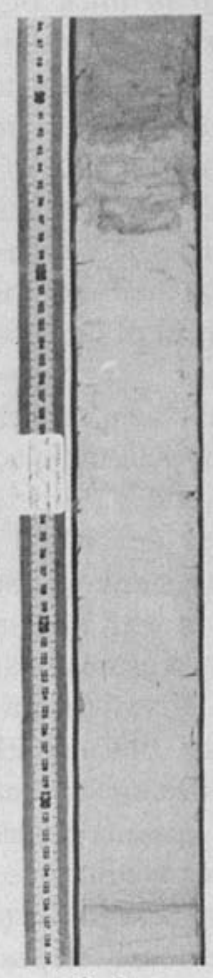

3. 2
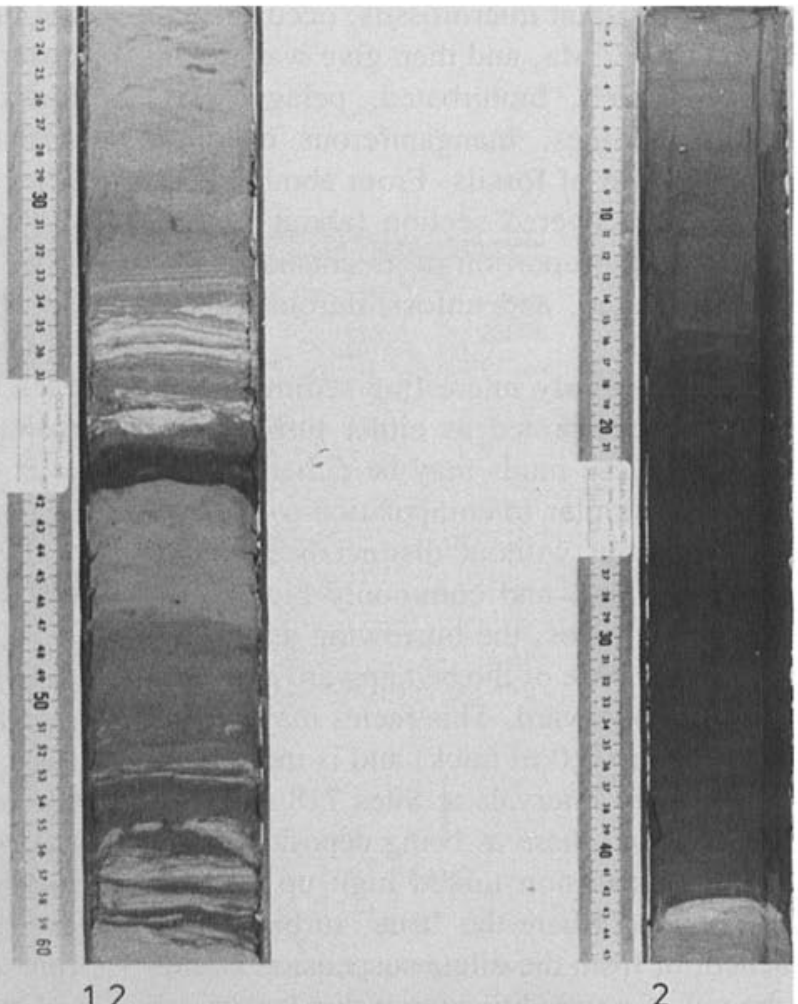

2

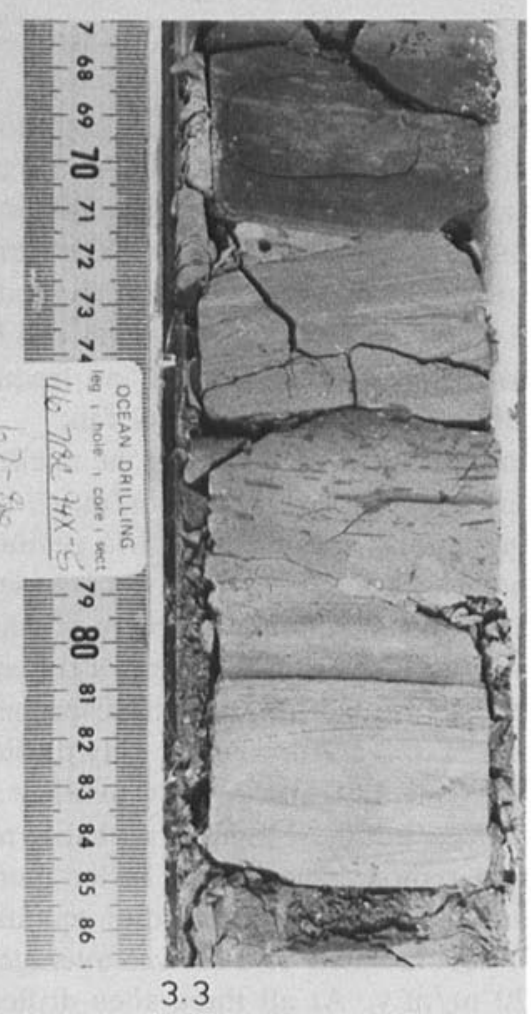

Figure 3. Continued on next page. 


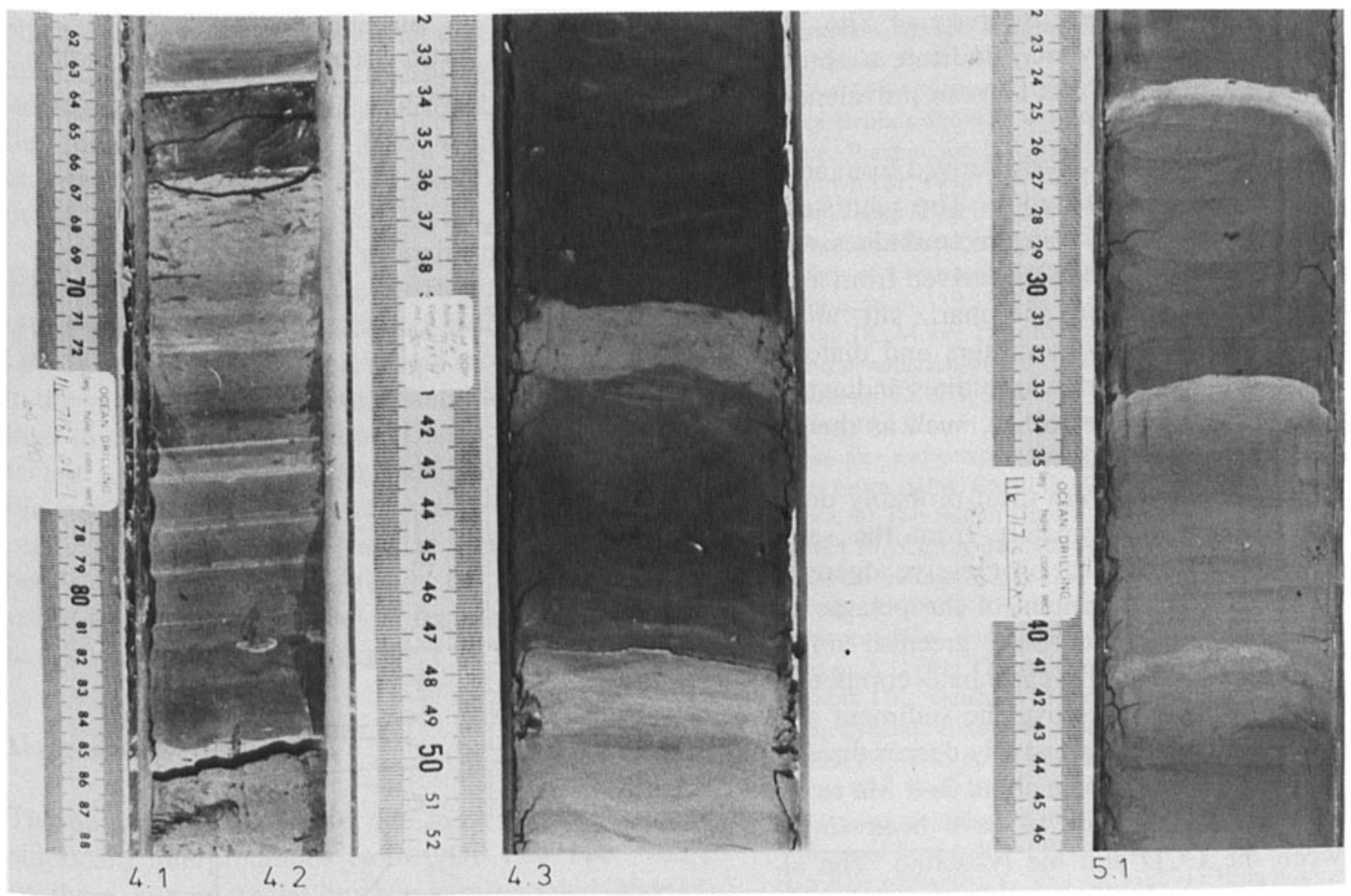

Figure 3. Continued from previous page. Selected photographs of sediment facies recovered from the distal Bengal Fan. Facies 1: gray silt and mud turbidites, Facies 2: organic-rich turbidites; Facies 3: biogenic turbidites; Facies 4: pelagic clays; Facies 5: pelagic oozes.

\section{Sediment Source}

Although the Bengal Fan is believed to be largely derived from erosion of the Himalayas, there is clear evidence in the cores recovered on Leg 116 for a more varied input to the distal fan. The dominant gray micaceous silts and silt-mud turbidites are interpreted as the signature from the Ganges Delta, partly because of their relative abundance and partly because of the complete absence of microfossils coupled with common terrigenous plant debris. Preliminary results from our heavy mineral studies (Amano, Personal Communication 1988) reveal a hornblende-epidote-zoisitegarnet-pyroxene suite characteristic of the gray silts throughout the sequence, together with lower amounts of sillimanite, kyanite, olivine, and pumpeyllite in certain zones. This is similar to the mineralogy of sediments recovered at Site 218 on the middle fan and interpreted as deriving from a Himalayan source (Thompson 1974).

In order to travel some $2,500 \mathrm{~km}$ and deposit 2.5 $\mathrm{m}$ thick turbidites, including coarse sand-sized quartz grains, the turbidity currents must have been very large. Major slumping of unstable delta-front sediments, perhaps into the head of the Swatch-of-no-Ground delta-front trough, seems the most likely process ini- tiating such large flows. This is very similar to the processes operating in the Mississippi Canyon, feeding turbidites to the Mississippi Fan (Coleman, Prior, and Lindsay 1983).

The dark gray, organic-carbon-rich muddy turbidites we believe derived from similar large-scale slumps on a more anoxic part of the upper slope. Further analyses should help determine whether these occurred on the slope at the northern end of the Bay of Bengal adjacent to the delta, or on the continental margin off eastern India and Sri Lanka. Subtle changes in both the heavy and light mineral fractions noted in our current studies (i.e. increase in labradorite and ilmenite, Amano, Personal Communication 1988) suggest that a part of the mud-rich sections (Units III and IV) were derived from the South India mainland rather than from the Himalayas. The shipboard analyses of clay minerals show an illite-dominated suite together with variable amounts of kaolinite, chlorite, smectite, and other more minor species. This is similar to the results from Site 218 reported by Pimm (1974), but our coverage is not yet sufficiently detailed to show any smectite enrichment that might indicate a South Indian Deccan Traps source (e.g. Venkatarathnam and Biscaye 1973).

The derivation of the thin green silt to brownish 
mud turbidites that occur near the base of Site 718 has not been resolved. They may indicate a source other than the Ganges Delta that is more prevalent in the older sedimentary record.

The biogenic turbidites are clearly derived from areas of significant pelagic sedimentation. The whitish or buff-colored carbonate silt-rich biogenic turbidites with pelagic foraminifers were probably derived from a local sea mount source; whereas the quartz silt, abundant clays and shelf-slope foraminifers and diatoms in the greenish nannofossil-rich turbidites indicate a source with more terrigenous influx, such as the Indian/Sri Lanka continental shelf.

The pelagic clay intervals are most probably dominated by clays derived ultimately from the same sources as the turbidites. The progressive decrease down-section in carbonate content of the pelagic intervals and the change from whitish to greenish to redbrown color indicates that the carbonate compensation depth (CCD) was well above the sediment surface at $17 \mathrm{Ma}$ but became progressively deeper through the Miocene and Pliocene. From about 2-3 Ma to the present, the sea floor appears to have been somewhere between the CCD and the lysocline. The almost complete absence of siliceous microfossils within pelagic intervals beneath the supposed equatorial highproductivity zone is a mystery. We believe that dissolution during early diagenesis has been a significant factor.

\section{Controls on Sedimentation}

Sedimentation on the distal Bengal Fan has been controlled by at least four distinct factors. A first order control has been the uplift of the Himalayas followed by erosion, which provided a massive supply of sediments to the coast via the Ganges-Brahmaputra drainage system. In a general way, the dominance of silty turbidites through much of the Miocene and in the late Pleistocene is probably related to two distinct phases of Himalayan uplift (Gansser 1964, 1981), corresponding to the beginning of motion on the main central thrust at 18 to $20 \mathrm{Ma}$, and to the most recent major phase of activity on the main boundary thrust at about $1 \mathrm{Ma}$.

A second important control has been sea level fluctuation. When the most recent low-frequency curve of eustatic sea floor changes (Haq and others 1987) is compared with the sedimentary record from the Leg 116 sites, there is a good correspondence in some but not all parts (Fig. 4). The abrupt change from the silty turbidites of Unit $V$ to the mud-dominated section of Unit IV is probably better explained by the rising of sea level in the late Miocene rather than by a sudden

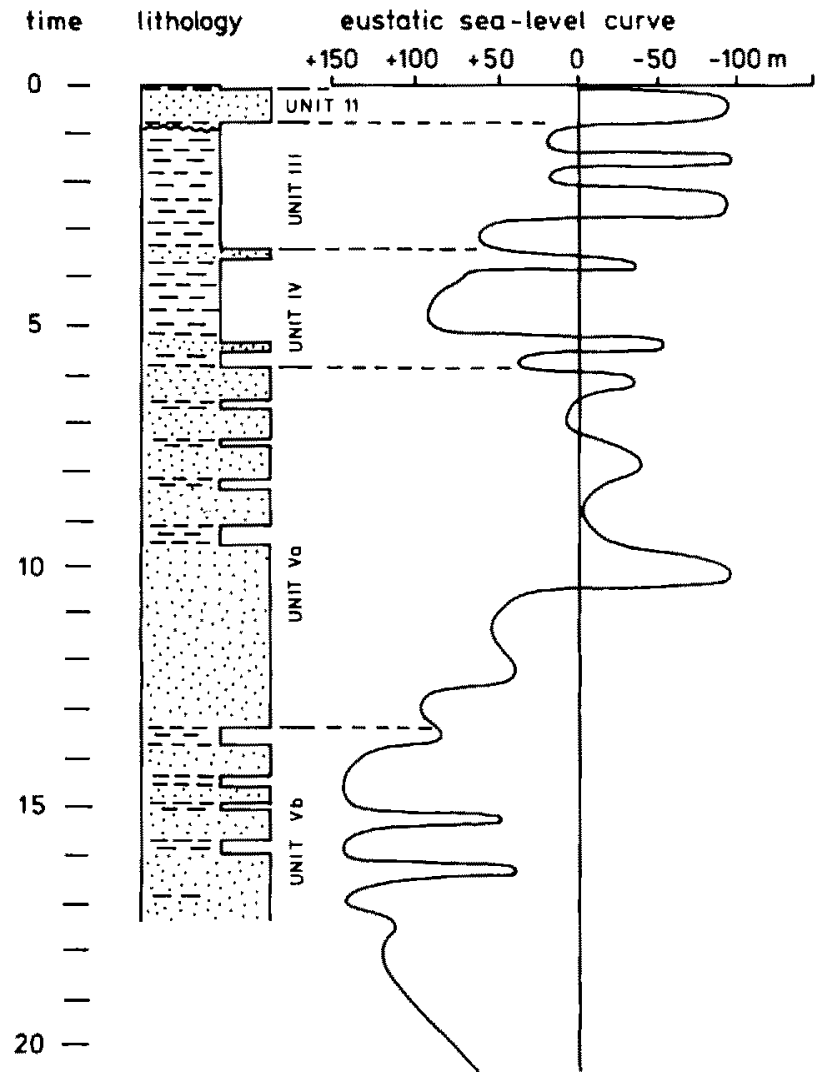

Figure 4. Eustatic sea level curve (after $\mathrm{Haq}$ and others 1987) compared with the summary lithostratigraphic section shown from the Leg 116 sites, plotted at the same time-interval scalc.

diminution of supply from a denuded Himalayan source. Similarly, the abrupt reappearance of the silty turbidites in the late Pleistocene (Unit II) seems likely to be partly a response to lowered sea level at that time. However, it may be reasonable to infer a cause and delayed effect relationship between the very major tectonic rejuvenation of the Himalayas in the midPleistocene at roughly $1 \mathrm{Ma}$ and the change from predominantly mud to sand-silt turbidites at about 0.85 Ma. Moreover, the mid-Miocene high stand and the many sea level oscillations through the Plio-Pleistocene are not all directly reflected in the sedimentary record. This is partly because low core-recovery in silty units decreases resolution but may also imply an overprint by a tectonic or other control.

There have also been local tectonic effects related to intraplate deformation and motion on the fauits. In particular, the marked reduction in thickness of Units III and IV at Sites 718 and 719 relative to 717 (Fig. 2 ), is related to their higher position on the fold/fault blocks. There is clear evidence from detailed core analysis that individual turbidites and recognizable groups of turbidites have been thinned and that others 
pinch out completely. It appears that even a slight elevated relief (say $10-50 \mathrm{~m}$ ) during deposition was sufficient to cause turbidity currents either to be deflected or, perhaps more likely, to thin and increase in velocity so that they passed into a non-depositional mode.

Normal processes of fan growth, including channel and lobe switching and the development of compensation cycles, have also affected sedimentation at the Leg 116 sites. It is possible that a more major change in the supply routes, for example to the Nicobar rather than to the Bengal Fan, could have significantly affected sedimentation in the study area. The $1 \mathrm{~m} . \mathrm{y}$. Pleistocene haitus, or condensed section, might be partly explained in this way. In addition, increased bottom circulation as a result of major climatic/ oceanographic changes may be required to prevent any deposition during this period.

\section{Conclusions}

The points outlined are for the most part preliminary shipboard interpretations from ODP Leg 116. Many of them remain to be further substantiated and refined. We have emphasized the results pertaining to fan sedimentation whereas more general preliminary results are given elsewhere (The Leg 116 Shipboard Scientific party $1987 \mathrm{a}, \mathrm{b})$. The most important conclusions are the following:

1. Turbidite sedimentation on the distal Bengal Fan was well underway by the early Miocene (about 17 Ma). This implies that major uplift and erosion of the Himalayas commenced prior to that time.

2. At least four distinct factors have influenced sedimentation: Himalayan uplift in the Miocene and Pleistocene, sea level fluctuations, local tectonic effects of intraplate deformation, and probable lobe/ channel switching.

3. Large turbidity currents have brought different materials to the distal fan from several distinct sources, including the Ganges Delta, the Indian-Sri Lankan margin, and local sea mounts.

4. The recognition of turbidite compensation cycles, the thinning and pinching out of turbidites over slight syn-depositional relief, and the occurrence of a distinctive sediment type with turbidite/hemipelagite characteristics, give important indications as to the nature of transport and deposition by large oceanic turbidity currents.

\section{References}

Bouma AH, Coleman JM, and others (1985) Mississippi Fan. DSDP Leg 96: Scismic surveys and drilling results. In: Bouma $\mathrm{AH}$,
Normark WR and Barnes NE (eds) Submarine Fans and Related Turbidite Systems. Springer-Verlag, New York, pp 245-339

Bouma AH, Coleman JM, and others (1986) Initial Reports Decp Sea Drilling Project, Volume 96. US Government Printing Office, Washington DC, 824 pp

Coleman JM, Prior DB, Lindsay JF (1983) Deltaic influences on shelf-edge instability processes. In: Stanley DJ, Moore GT (eds) The Shelf Brak: Critical Interface on Continental Margins. Society of Economic Palaeontologists and Mineralogists Special Publication 33:121-137

Curray JR, Moore DG (1971) Growth of the Bengal decp-sea fan and denudation of the Himalayas. Geological Society America Bulletin 82:563-572

Curray JR, Emmel FJ, Moore DG, Raitt RW (1982) Structure, tectonics and geological history of the north eastern Indian Occan. In: Nairn AEM, Stchli FG (cds) The Ocean Basins and Margins (Vol 6) The Indian Ocean. Plenum Press, pp 399-450

Emmel FJ. Curray JR (1984) The Bengal submarine fan, northeastern Indian Occan. Geo-Marine Letters 3:119-124

Gansser A (1964) The Geology of the Himalayas. Wiley Interscience, New York, $289 \mathrm{pp}$

Gansser A (1981) The geodynamic evolution of the Himalaya. In: Gupta HK, Delany FM (eds) Zagros, Hundu Kush, Himalaya Geodynamic Evolution. American Gcophysical Union Geodynamic Sorics 4 , pp $111-121$

Geller CA, Weissel JK, Anderson RN (1983) Heat transfer and intraplate deformation in the central Indian Ocean. Joumal Geophysical Research 88:1018 -1032

Haq BU, Hardenbol J, Vail PR (1987) Chronology of fluctuating sca levels since the Triassic. Science $235: 1156-1167$

Hayes DE, Pimm AC, and others (1973) Site 142. Initial Reports Deep Sea Drilling Project, Vol 14 U.S. Government Printing Office, Washington $D C$.

Mutti E, Normark WR (1987) Comparing examples of modern and ancient turbidite systems: problems and concepts. In: Leggett JK, Zuffa GG (eds) Marine Clastic Sedimentology: Concepts and Case Studies, Graham and Trotman, London, pp 1-37

Mutti E, Sonnino M (1981) Compensation cycles: a diagnostic feature of turbidite sandstone lobes. International Association Sedimentologists 2 nd European Regional Meeting. Bologna, Italy, Abstracts, pp 120-123

Pimm AC (1974) Sedimentology and history of the NE Indian Ocean from late Cretaceous to Recent. In: Von der Borsch CC, Sclater $\mathrm{JC}$ et al, Initial Reports of the Deep Sea Drilling Project, Vol. 22. U.S. Government Printing Office, Washington DC. pp 717 803

Ryan WBF, Hsu KJ et al (1973) Site 131. Initial Reports Decp Sea Drilling Project, Volume 13. U.S. Government Printing Office, Washington $D C$

Simpson E, Schlich J, and others (1974) Sites 243, 244 and 248. Initial Reports Deep Sea Drilling Project, Volume 25. U.S. Government Printing Office, Washington DC

Stow DAV (1985) Deep-sea clastics: where are we and where are we going? In: Brenchley PJ, Williams BPJ (eds) Sedimentology: Recent Developments and Applied Aspects, Geological Society Special Publication No 18. Blackwell Scientific Publications. Oxford, pp 67-94

Stow DAV, Howell DG, Nelson CH (1983) Sedimentary, tectonic and sea level controls on submarine fan and slope-apron turbidite systems. Geo-Marine Letters 3:57-64

Stow DAV and others (1986) Facies, composition and texture of Mississippi Fan sediments, DSDP Leg 96, Gulf of Mexico. Initial Reports Deep Sca Drilling Project, Volume 96:475-487

The Leg 116 Shipboard Scientific Party (1987a) Collisions in the Indian Ocean. Nature 330:519-521

The Leg 116 Shipboard Scicntific Party (1987b) Himalayan uplift 
history observed on the equator. Geotimes 33(1):9-12 Thompson RW (1974) Mineralogy of sands from the Bengal and Nicobar fans, Sites 218 and 211 , eastem Indian Occan. In: Von der Borsch CC. Sclater JC, and others Initial Reports of the Deep Sca Drilling Project, Volume 22. U.S. Government Printing Office, Washington DC, pp 711-713

Venkatathnam K, Biscaye PE (1973) Clay mineralogy and sedimentation in the castern Indian Ocean. Decp-Sea Research $20: 727-738$

Von der Borsch CC, Sclater JG, and others (1974) Site 218. Initial
Reports Deep Sea Drilling Project, Volume 22. U.S. Government Printing Office Washington, DC, 325-348

Weissel JK, Anderson RN, Geller CA (1980) Deformation of the Indo-Australian plate. Nature 287:284-291

Whitmarsh RB, Weser OE, Ross DA, and others (1974) Site 222. Initial Reports Deep Sea Drilling Project, Volume 23. U.S. Government Printing Office Washington, DC, pp $211-289$.

Manuscript received 17 September 1987; revision received $22 \mathrm{Au}-$ gust 1988. 